\title{
Edith Silverglied Lisansky Gomberg, PhD 1920-2005
}

\author{
Robert A. Zucker
}

$\mathrm{E}^{\mathrm{s}}$ DITH SILVERGLIED LISANSKY Gomberg, PhD, Professor of Psychology in Psychiatry, emerita at the University of Michigan, died peacefully in her sleep on Sunday January 9, just 5 days short of her 85th birthday. Described by Sharon Wilsnack, an international authority on alcohol problems in women, as "truly the "grandmother' of gender and alcohol research," she was schooled at a time when women were neither expected, nor sometimes permitted, to achieve academic status. Born and raised in New York City, she earned a BA in Psychology from Brooklyn College at 18 and an MA in social psychology from Columbia at 20. When she was told by her advisor, the eminent social psychologist Otto Kleinberg, that women did not need a PhD, she headed north to New Haven. Her doctoral work at Yale was a precursor to what later became the clinical psychology degree and involved work in clinical, social, and experimental psychology. She finished at 29 and in the midst of raising a family began a long association with the Yale Center of Alcohol Studies, at that time the only academic/research center on alcohol in the United States.

This was a time when the alcohol field was just developing as an area of scientific respectability. E. M. Jellinek was a major presence at the Center but his writing on the disease concept of alcoholism was still more than a decade away, and the then Quarterly (sic) Journal of Studies on Alcohol had been published for less than a decade. Gomberg's early publications were more clinically focused, and not all were related to alcoholism (e.g., Lisansky, 1948; 1950), but by the mid-1950s, she had moved to the groundbreaking work she was known for thereafter, describing the characteristics of women alcoholics, their psychosocial adaptations, their problems, and their lives as women (Gomberg, 1989a; Lisansky, 1957; 1958). This work remained a major theme throughout her career. Edith moved from this to the more general topic of problem drinking among women (e.g., Gomberg, 1988; 1989b) not a popular subject in those years since women were thought not to suffer from such problems at all. She took it upon herself to ask questions, provide data, and inform the sci-

From the University of Michigan Addiction Research Center, Ann Arbor, Michigan.

Received for publication December 7, 2005; accepted December 7, 2005. Copyright (C) 2006 by the Research Society on Alcoholism.

DOI: 10.1111/j.1530-0277.2006.00043.x entific and clinical communities about these issues, and she remained a leader in research on women's drinking and alcoholism in women until the end of her career (Gomberg and Nerenberg, 1993). Her continuing support and encouragement of women who entered the alcohol research field, along with a vigorous program of lecturing, made her an icon to many who did not know her personally. She also was a vigorous spokeswoman and advocate for more focused treatment that would speak to women's special needs.

Gomberg's academic career spanned five institutions: Yale, then Rutgers, where she sustained collaborations with old colleagues and friends at the Alcohol Studies Center after it had moved from New Haven to New Brunswick, the University of Puerto Rico, the Ann Arbor VA Medical Center, and for the last three decades of her career, the University of Michigan. There she held appointments in the Institute of Gerontology, the Institute of Social Research, the School of Social Work, and the Addiction Research Center/Department of Psychiatry. At Michigan, Edith's work broadened to focus on another neglected area, understanding the problems of alcohol and prescription drug abuse among older people (e.g., Gomberg, 1990, 1992). She also began a program of work to understand drinking behavior among African Americans and to describe the ways that treatment process needed to take account of cultural differences (Nelson et al., 1997). In the late 1980s she was part of the core faculty group involved in bringing the first national NIAAA Center on Alcohol and Aging to Michigan, and that center, the University of Michigan Alcohol Research Center, is the forerunner of what is today's University of Michigan Addiction Research Center. During those years she also coedited two of the major works on alcohol involvement and aging (Alcohol and Aging, with Beresford; Oxford, 1995) and the NIAAA Research Monograph on Alcohol Problems and Aging (with Zucker and Hegedus, 1998).

Gomberg remained a presence both nationally and internationally on the effects of alcohol on women and alcohol and aging until her retirement, and she continued to write and correspond with others about their work until the end of her life. Those who knew her will remember Edith's spark, her sense of humor, her broad span of interests, her ability to "tell it like it is," and her special knack to stay down-to-earth and connected with so many people from diverse backgrounds. She will be missed 
greatly as a friend and remembered for how much she did for the alcohol field. She is survived by five children.

The family has created a memorial website (www. edithgomberg.com) that provides some sense of the vitality of her life. A memorial fund at the Research Society on Alcoholism (RSA) has also been set up in Gomberg's name, out of which an award will be created. Donations may be made directly to RSA, with the explicit designation that they are for "the Edith Gomberg Fund."

\section{REFERENCES}

Beresford TP, Gomberg ESL (eds) (1995) Alcohol and Aging. Oxford University Press, New York.

Gomberg ESL (1988) Shame and guilt issues among women alcoholics. Alcohol Treat Q 4:139-155.

Gomberg ESL (1989a) Alcoholic women in treatment: early histories and early problem behaviors. Adv Alcohol Subst Abus 11:133-147.

Gomberg ESL (1989b) Suicide risk among women with alcohol problems. Am J Public Health 79:1363-1366.

Gomberg ESL (1990) Drugs, alcohol and aging. in Research Advances in Alcohol and Drug Problems, Vol. 10 (Kozlowski LT, Annis HM,
Cappell HD, Glaser FB, Goodstadt MS, Israel Y, Kalant H, Sellers E M, Vingilis ER, eds), pp. 171-213. Plenum Press, New York.

Gomberg ESL (1992) Medication problems and drug abuse. in Mental Health.and the Elderly (Turner FL ed), pp. 335-374. The Free Press, New York.

Gomberg ESL, Nirenberg TO (eds) (1993) Women and Substance Abuse. Ablex Press, Norwood, NJ.

Gomberg ESL, Hegedus AM, Zucker RA (eds) (1998) Alcohol Problems and Aging. (NIAAA Research Monograph No. 33. NIH Pub. No. 984163). National Institute on Alcohol Abuse and Alcoholism, Bethesda, MD.

Lisansky ES (1948) Convulsive disorder and personality. J Abnorm Soc Psychol 48:28-17.

Lisansky ES (1950) The role of the clinical psychologist in an alcoholism clinic. Conn Rev Alcohol 1:16.

Lisansky ES (1957) Alcoholism in women: social and psychological concomitants. I. Social history data. Q J Stud Alcohol 15:588-623.

Lisansky ES (1958) The woman alcoholic. Ann Am Acad Political Soc Sci 315:78-81.

Nelson BW, Blow FC, Gomberg ESL, Coyne JA, Walton MA, Barry KL (1997) Racial differences in alcohol use among older adults (Abstract). Alcohol Clin Exp Res 21:25A. 